\title{
The future role of natural gas in Saudi Arabia
}

\author{
Prof.Dr. Mohamed Morsy Elgohary and Captin Khalil Hemida \\ Faculty of Maritime studies, King Abdul Aziz University, Jeddah, Saudi Arabia \\ Accepted 18 Oct 2015, Available online 22 Oct 2015, Vol.3 (Sept/Oct 2015 issue)
}

\begin{abstract}
Despite the attractiveness and extraordinary progress of many nations and world commerce, since industrial revolutions in the $20^{\text {th }}$ century by fossil fuel, it's the major source of many social problems and concerns, as environmental hazards and sustainability issues. The following assessment is focused on analyzing the functions of floating, storage, offloading and production of offshore oil vessels. Information related to the technology, design, operation and project management of these vessels from a marine perspective has been presented likewise. Observing the rapid digitalization of the modern world, researchers have significantly deployed numerous strategies in order to integrate technology for provisioning better end services while constructing these vessels. However, the detailed information on oil and gas processing as well as the complex engineering assessments are nevertheless avoided in the following assessment.
\end{abstract}

Keywords: Natural Gas, FLNG: Floating liquefied natural gas and alternative fuels.

\section{Abbreviation}

TCF: Trillion Cubic Feet

Bbbl: Billion barrel of 42 US gallons of oil

FPSO: Floating, production, storage and offloading system

FLNG: Floating liquefied natural gas

HSE: Health, safety and environment

\section{Introduction}

This year oil prices peaked above $45 \$$ per barrel and expected to rise in the next years. This price hike can be linked to large increase in demand on oil to meet rapidly growing population and economy. World population is expected to continue growing during next years, ensuring emphasis on sea borne trade.

It's being known that the global oil supplies will only meet the demand until global oil production has peaked sometimes between 2013-2030[1],causing a serious energy shortage in next decades. Oil industry analysts state that the residual fuel (HFO) will become too valuable used as a feedstock for refiner to undergo cracking operation producing more valuable light fuels. Refineries worldwide are also moving in the same direction.

The oil reserves of Saudi Arabia are the fifth largest reserves in the world. It has significantly contributed in exporting petroleum liquids all across the globe and has now become the world's largest producers of the petroleum liquids. Observing the current economical market, it has been evaluated that the core industry of the Saudi market assimilates oil and gas, In order to ensure continuous development of the country; it is necessary for the Saudi government to implement new and innovative ideas which may result beneficiary for the country to prosper economically in the near future.

\section{Current situation of bunker fuel and international regulations}

Currently most of motor ships are powered by HFO or diesel oil, both are nonrenewable resources, derived from petroleum refineries. The increase in world demand for oil distillate products led to the refinery increased usage of catalytic and thermal secondary conversion instead of simple distillation process [elgohary2013].These developments have had a direct impact on the fuel quality of marine fuel oil by promoting a gradual shift away from low viscosity grades to higher viscosity ,density, carbon residue, Sulphur and ash content, simply because the cracked residues and diluents are inherently heavier than their straight run counter parts.

Because more than $50 \%$ of ship's operating expense is generally the closet of fuel oil, most of ships owner use degraded residue heavy fuel oil in marine power plants for its economy, availability, ease of use, high energy density.

This leads to many impacts on the prime mover itself like increased wear rate in cylinder liner and piston rings (abrasive-adhesion-corrosion) ref [review2004] and very poor ignition qualities, which result in combustion problems that can badly damage the combustion 
components of diesel engine ref [Elgohary 2013], the increased wear is due to Sulphur content which is the principle of non-hydrocarbon in all marine fuels. Its naturally occurring element in crude oil which is more concentrated in residual components and its amount of the fuel depend on both source of the crude oil and the refining processes. However, the corrosive wear resulting from the burning of the Sulphur in fuel can be controlled by an alkaline lubricant and suitable lubrications.

$\mathrm{R} F$ Tomas introduce the relationship between the seaworthiness (concept of suitability and safeness) and the fuel quality delivered to the ship where variable quality of fuel is commonplace, subsequent onboard fue treatment.

In addition to the impacts on the engine performance the production and refinery and transportation, use of these fuel cause local and global impact on environmental.

After the changing of previous view about ship emissions (not significant-offshore so no impact and difficult to control) to (significant amount $14 \% \mathrm{No}_{x}, 5 \%$ Sox, $2 \% \mathrm{CO}_{2}$. The table below summarizes the available methods for reducing ship emissions.

\begin{tabular}{|l|l|l|l|}
\hline Source & Component & Reduction method & $\begin{array}{l}\text { Potential for } \\
\text { reduction }\end{array}$ \\
\hline \multicolumn{3}{|c|}{} \\
\hline Diesel engine & NOx & Selective catalytic reduction & $95 \%$ \\
\hline & & Emulsification & $20-25 \%$ \\
\hline & & Humid Air Method & $70 \%$ \\
\hline & & Direct water injection & $50-60 \%$ \\
\hline & & Engine tuning & $10-30 \%$ \\
\hline & & Exhaust gas re-circulation & $80 \%$ \\
\hline & Sulphur content in fuel & $30-70 \%$ \\
\hline & & $\begin{array}{l}\text { Sea water scrubbing } \\
\text { Scrubber } \\
\text { exhaust below water line }\end{array}$ & $80-95 \%$ \\
\hline & & Emulsification & $40 \%$ \\
\hline & CO & Electrostatic filters & $25-60 \%$ \\
\hline & Particles & & \\
\hline & & &
\end{tabular}

\section{Alternative fuel}

Any new fuel to be introduced should be evaluated from the aspects of availability, renewability, safety ,cost, adaptability to the existing engine, performance, economy and finally emission regulations, the alternatives fuels can be used in (maritime transportations) are as follows,

1-Coal: Although the introduction of coal-oil and coal water moisture (COM\&CWM) and advances in technology of coal firing processes as mechanical stroke-pulverized coal-fluidized bed combustion. It's completely outside IMO regulations due to its higher Sulphur content, but the flue gases can be reduced to limits with expensive processes.

2-Hydrogen: In comparison to other alternative fuels, hydrogen seems to provide the most satisfactory problem of sustainability, because it has almost in-exhaustible natural source in water. Unlike fossil fuel it does not occur free in nature and primary energy source is necessary to separate it from its original combined state. The following methods are suitable for hydrogen production from water (El-gohary and elshrife 2006)

1) thermal decomposition of water : in this method heat at high temperature $(3000 \mathrm{C})$ is used to decompose water into $\mathrm{H}_{2}$ and $\mathrm{O} 2$
2) electrolysis of water: in this method electrical energy is used to brake water into $\mathrm{H} 2$ and $\mathrm{O} 2$

3) thermo chemical method: this consider the most promising method depending on the complex serious of reaction between primary energy, water, some catalyst to produce hydrogen at temperature much lower than thermal decomposition

4) photobialysis: in this method hydrogen is produced from water under the effect of certain catalyst and direct sunlight at ambient temperature.

Hydrogen can be also produced by steam reforming of NG into synthesis gas, from which $\mathrm{CO} 2$ and $\mathrm{CO}$ are removed.

3-Natural gas: Natural gas is well established as a major contributor to the world's energy needs due to its availability, it derived from raw gas from offshore or onshore field as a dry, light fraction and mainly comprise from methane and some ethane. It is available directly at the gas field itself, in pipeline systems, condensed into liquid as LNG or compressed as CNG. The NG has lower level of noxious emission, carbon dioxide $(20 \%$ than standard diesel), good combustion Characteristics (its ignition temperature about $600 \mathrm{C}$ ), led to reduction in maintenance and longer interval of overhaul (El-Gohary, M. M., 2012-2015).

This gives a growing opportunities for duel fuel and gas diesel engine in land and marine power market as 
floating oil production vessels, offshore support vessels and LNG carrier (currently using its BOG instead of release to air); Ropax ferries and small Norwegian ferries have also been proposed with duel- fuel diesel propulsion by using a natural gas as a bunker fuel (El Gohary, M. M., and Seddiek, I. S. 2013)..

The introduction of natural gas onboard commercial ships introduces a lot of questions regarding the safety, gas storage, environmental aspects, classification , regulations view and engine conversion: Natural gas can be stored either CNG or as LNG comparison between both is give in the following figure (1)

The figure shows that the CNG tank is heavier and takes approximately 5 times the volume of diesel fuel; however LNG is only $50 \%$ heavier than diesel and requires less tank space approximately twice that of diesel. These differences make that LNG is better solution for replacing diesel fuel than CNG

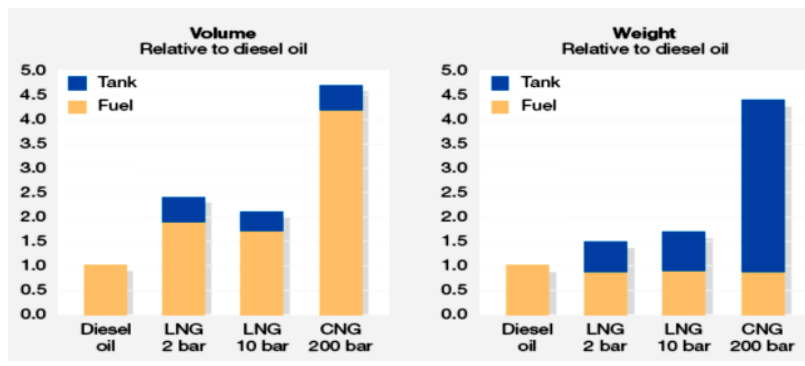

Fig (1): Relative space demand and weight for the storage of LNG and compressed natural gas (CNG) compared to that of diesel fuels.

\section{LNG reservation in Saudi Arabia}

It was not until the year 2007 that the initiative for implementing technology became imminent, when one of the major oil production organizations of Saudi Arab, The Saudi Aramco, decided to increment their productivity to more than $2 \mathrm{MMb} / \mathrm{d}$ (Million Barrels per day). Observing that the majority productions of the oil field were coming in from onshore fields such as the Ghawar field, the need to utilize offshore field became more of a necessity rather than a need. Currently, the Safaniya field is the world's largest offshore reservoir with an estimated production of 25-35 Bbbl of heavy crude oil. Similarly, multiple other fields were identified such as the Manifa field estimating a total of $10 \mathrm{Bbbl}$ of heavy crude, Abu Safah, Zuluf, Marjan and Berri all located in different regions of Saudi Arabia. The recent discovery of the Karan field is considered the largest reservoir for natural gas reserves assimilating a total of 9 tcf. The oil extraction organizations of Saudi Arabia has significantly focused on onshore fields rather than offshore fields, however, considering the long coast of Saudi Arabia and the mild tidal conditions in comparison to other marine regions of the globe, exploitations of oil and gas production are commendably fulfilled through deployment of floating facilities.

\section{Floating Liquefied Natural Gas (FLNG)}

FLNG refers to the incorporation of technologies for water based liquefied natural gas (LNG) operations. Such designs enable the development of offshore storage and processing of natural gas resources. Currently, no such FLNG exists; however, the facility is under development by the Royal Dutch Shell and is hopeful to be completed by year 2017. Theoretically, the floating above the shore, an FLNG is capable of producing, liquefying, storing and transferring LNG at sea. The extracted LNG is then transferred to carrier ships that transmit the extracted resources directly to the specified market.

FLNG has the capability to carry out all necessary processes for producing, storing and offloading LNG. The FLNG technology helps Organizing certain specifications such as the location of the resource, the depth of the sea, the category of resource, the interest of organizations, identification of fields and mitigating key contractors helps the engineers to evaluate the potential requirements for designing an FLNG.

The design of an effective functioning LNG requires the following five basic components.

Subsea equipment for extraction of gas from the reservoir, Risers and umbilical for seabed/surface interfaces, Turret, Hull \& Storage; and Topside processing facilities.

The initial concept of an LNG deployment inquires the research of the area where the Floating LNG is to be implemented or deployed within the respective region (Howell 2006). Organizing certain specifications such as the location of the resource, the depth of the sea, the category of resource, the interest of organizations, identification of fields and mitigating key contractors helps the engineers to evaluate the potential requirements for designing an FLNG.

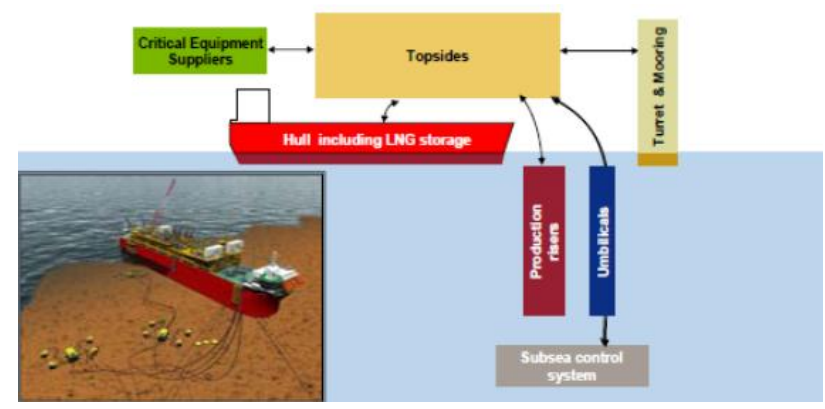

Fig. 2: The Concept of FLNG

The FLNG facility is initially positioned directly above an identified underwater natural gas field. The system then transmits the gas from the respective field of natural gas to the facility where risers are located. The transmitted gas is then processed to produce further natural gas, LPG 
and respective condensates (Eia.gov., 2014). The processed gas is then treated in order to remove impurities from the extracted resource by freezing the gas before it is transferred into a hull. Once the impurities are removed the gas is then transferred to the ocean-going carriers for offloading by-products in the oil and petroleum market worldwide.

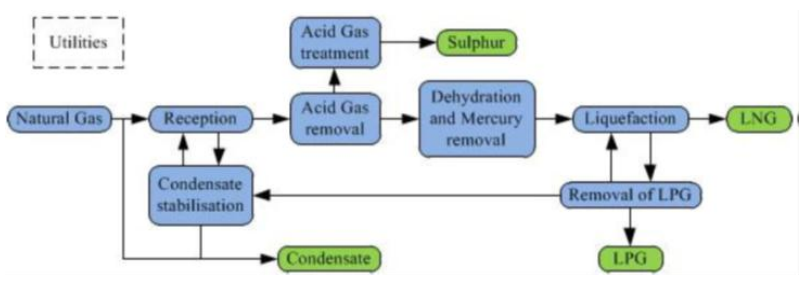

Fig 3: FLNG Process Layout

\section{Conclusions}

From the previous analysis, it can be concluded that:

1- Currently most diesel engine can meet regulation with some economic penalty.

2- Increase the infrastructure and logistic and supports for bunkering LNG

3- FLNG is effective such offshore production systems that can easily facilitate the oil and gas production within a particular vicinity. They are a profitable investment since these systems can be deployed in various fields within the respective boundaries of the country or outside 9. Their mobility and ease of disconnection makes them an excellent offshore facility to be utilized. Their major applications are identified in the gulf area where the weather conditions are quite mild. Currently, organizations are investing to entrepreneur such systems that can significantly curtail down the complexities of extracting offshore natural resources

This report is prepared for the aim of providing an introduction to the idea of FLNG technologies but frankly for such an important and multi-million investments, a considerate study and research is necessary.

\section{Recommendation}

Currently, Shell has invested to acquire the revolutionary technology that will develop the world's first Prelude FLNG system. The prelude prototype is capable of extracting oil at a depth of 250 meters below sea level at an average production capacity of 5.3 million tonnes per annum of liquid. The contractor for a business is Technip Samsung Consortium whereas the working partners for the following project incorporates Shell itself at the market share of 67.5 percent, Inpex at 17.5 percent, CPC at 5 percent and Kogas at 10 percent.

The Prelude FLNG is currently being designed at Samsung Heavy Industries at Geoje Island shipyards located in South Korea. Once construction is completed the technology will be hooked and moored to the undersea petroleum extraction infrastructure at approximately 475 kilometers north-northeast of Broome, Western Australia. The project opens up an opportunity for almost 300 to 350 direct and indirect workers. The facility is capable of performing its effective functions for a time span of twenty-five years.

Observing and researching in coordination of the Shell Industries, the Saudi government can significantly result in creating their own respective FLNG technology for extraction of commendable natural resources.

\section{References}

[1]. Burton, E. (2009). Saudi Arabia aims to bolster offshore oil and gas program. Offshore, 69(9). Retrieved from http://cat.inist.fr/?aModele=afficheN\&cpsidt=22001949

[2]. El Gohary, M. M., \& Seddiek, I. S. (2013). Utilization of alternative marine fuels for gas turbine power plant onboard ships. International Journal of Naval Architecture and Ocean Engineering, 5(1), 21-32.

[3]. El-Gohary, M. M. (2013). Overview of past, present and future marine power plants. Journal of Marine Science and Application, 12(2), 219-227.

[4]. Elgohary, M. M., \& Seddiek, I. S. (2012). Comparison between Natural Gas and Diesel Fuel Oil Onboard Gas Turbine Powered Ships. Journal of King Abdulaziz University, 23(2), 109.

[5]. El Gohary, M. M. (2013). Environmental analysis of present and future fuels in 2D simple model marine gas tubines. International Journal of Naval Architecture and Ocean Engineering, 5(4), 559568.

[6]. El Gohary, M. M., Welaya, Y. M., \& Saad, A. A. (2014). The use of hydrogen as a fuel for inland waterway units. Journal of Marine Science and Application,13(2), 212-217.

[7]. El-Gohary, M. M. (2012). The future of natural gas as a fuel in marine gas turbine for LNG carriers. Proceedings of the Institution of Mechanical Engineers, Part M: Journal of Engineering for the Maritime Environment, 1475090212441444.

[8]. El-Gohary, M. M. (2013). Economical analysis of combined fuel cell generators and absorption chillers. Alexandria Engineering Journal, 52(2), 151-158.

[9]. Morsy El Gohary, M., and H. A. El-Sherif. "Future of hydrogen as green energy in marine application." 9th World Renewable Energy Congress. 2006

[10]. El-Gohary, M. Morsy. "Economical analysis of combined fuel cell generators and absorption chillers." Alexandria Engineering Journal 52.2 (2013): 151-158.

[11]. Eia.gov, (2014). U.S. Energy Information Administration (EIA). Retrieved on 16 September 2014, from http://www.eia.gov/countries/country-data.cfm?fips=sa

[12]. G. Boyd Howell, Arun S. Duggal, Casper Heyl and Oise Ihonde (2006). Spread moored or turret moored FPSOs for deep water field developments. Offshore West Africa. Retrieved from http:// www.sofec .com/white

[13]. Hillyard, J. F. (2012), Oil \& Gas Industry A Nontechnical Guide, Oklahoma: PennWell Corporation. Retrieved from http://books.google.com/books?isbn=159370254X

[14]. Ma, G., \& Sun, L. (2012). The Design and Implement of FPSO Assets Management System. Procedia Environmental Sciences, 12, 484 490. doi: 10.1016/j.proenv.2012.01.307

[15]. Radwan, A., Morsy, M. and Elbadan (2007), A., Economical and environmental advantages of using NG as a fuel in inland water transport., cimac07 conference

[16]. Report no. 377 (2006), 'Guideline for managing marine risks associated with FPSOs', International Association for oil and gas producer. Retrieved from www.ogp.org.uk/pubs/377.pdf

[17]. Seddiek, I. S., Ammar, N. R., \& El Gohary, M. M. (2015). Steam and Sofc Based Reforming Options of PEM Fuel Cells for marine applications. Brodogradnja, 66(2)

[18]. Seddiek, I. S., \& Elgohary, M. M. (2014). Eco-friendly selection of ship emissions reduction strategies with emphasis on SOx and NOx emissions. IJNAOE, 6(3), 737-748. 